\title{
TEMATISASI DESAIN: STUDI BEHAVIOR SETTING PENGGUNA TERHADAP TEMA RUANG PERPUSTAKAAN
}

\author{
Ahmad Ibrahim Rahmani*1, Abd. Karim², \\ Jurusan Teknik Arsitektur Universitas Islam Negeri Alauddin ${ }^{1}$, Universitas Gadjah Mada ${ }^{2}$ \\ *Correspondence author: Ahmad Ibrahim Rahmani, ahmad.ibrahim@uin-alauddin.ac.id, Makassar, Indonesia
}

\begin{abstract}
Abstrak. Penelitian ini dilakukan dengan mengidentifikasi tata perilaku (behavior setting) pengguna perpustakan dalam fenomena tematisasi ruang perpustakaan, lokus penelitian pada ruang NBC (National Building Corner) Universitas Gadjah Mada. Dengan menggunakan pendekatan studi perilaku dalam kerangka paradigma rasionalistik dan metode penelitian kualitatif, penelitian ini menunjukkan tata perilaku pengunjung cenderung menciptakan proses tematisasi ruang sehingga secara pragmatik menghasilkan kesimpulan bahwa meskipun pada awalnya ruangan ini di desain dengan tujuan dan fungsi tertentu, namun hal ini dapat senantiasa berubah sesuai dengan tata perilaku pengguna ruang nya. Fleksibilitas tema ruang yang terjadi dari tema ruang hiburan, edukasi, dan sosial di ruang National Building Corner Universitas Gadjah Mada ini dipengaruhi oleh tata perilaku pengguna ruang dalam mengokupansi area yang ada.
\end{abstract}

Kata Kunci: tata perilaku, temtisasi, ruang tematik

\begin{abstract}
This research was conducted by identifying the behavior setting of visitors in the phenomenon of room thematization in library, research locus in NBC (National Building Corner) Universitas Gadjah Mada. By using a behavioral study approach within the framework of a rationalistic paradigm and qualitative research methods, this study shows that visitor behavior tends to create a process of thematization of space so that pragmatically produces the conclusion that although this room was originally designed with specific goals and functions, this can always change according to the user's behavior. The flexibility of the space theme that occurs from the theme of entertainment, education, and social space in the National Building Corner Universitas Gadjah Mada room is influenced by the behavior setting of visitors in occupying the existing area.
\end{abstract}

Keywords: behavior setting, thematization, theme space

\section{Pendahuluan}

Perkembangan fungsi perpustakaan yang merupakan salah satu sarana paling mendasar dari sebuah layanan perguruan tinggi saat ini sangat pesat. Perpustakaan bertujuan untuk memelihara dan meningkatkan efisiensi dan efektifitas proses belajar-mengajar. Perpustakaan yang terorganisir secara baik dan sistematis, secara langsung atau pun tidak langsung dapat memberikan kemudahan bagi proses belajar mengajar di sekolah tempat perpustakaan tersebut berada (Sari and Pramitasari 2019). Perpustakaan saat ini tidak hanya digunakan untuk membaca, meminjam buku atau jurnal ilmiah saja, melainkan fungsinya sudah berkembang pesat sebagai tempat untuk mengerjakan tugas secara mandiri, mengakses layanan internet, dan atau hanya sekedar tempat berdiskusi berkelompok. Hal ini membuat ruang layanan di 
perpustakaan juga menjadi sangat variatif, seperti halnya berkembang ruang-ruang khusus dengan tema tertentu.

National Building Corner (NBC) sebagai salah ruang khusus yang ditujukan untuk menyediakan layanan berupa buku dan tayangan audio visual berisi pemikiran, gagasan, biografi para tokoh kebangsaan dan informasi-informasi lain terkait dengan proses pembangunan bangsa Indonesia. Seperti halnya di universitas ternama lainnya layanan National Building Corner juga sudah hadir di perpustakaan Universitas Gadjah Mada. National Building Corner menempati Ruangan pada Layanan Referensi dan Terbitan Berkala di Gedung L6 lantai 1 Perpustakaan Universitas Gadjah Mada dan dilayankan untuk dibaca di tempat, dengan jam Pelayanan: Senin/Kamis 07:30-19.45 WIB, Jum'at 07:30-19.00 WIB dan Sabtu 08:00-12:00 WIB.
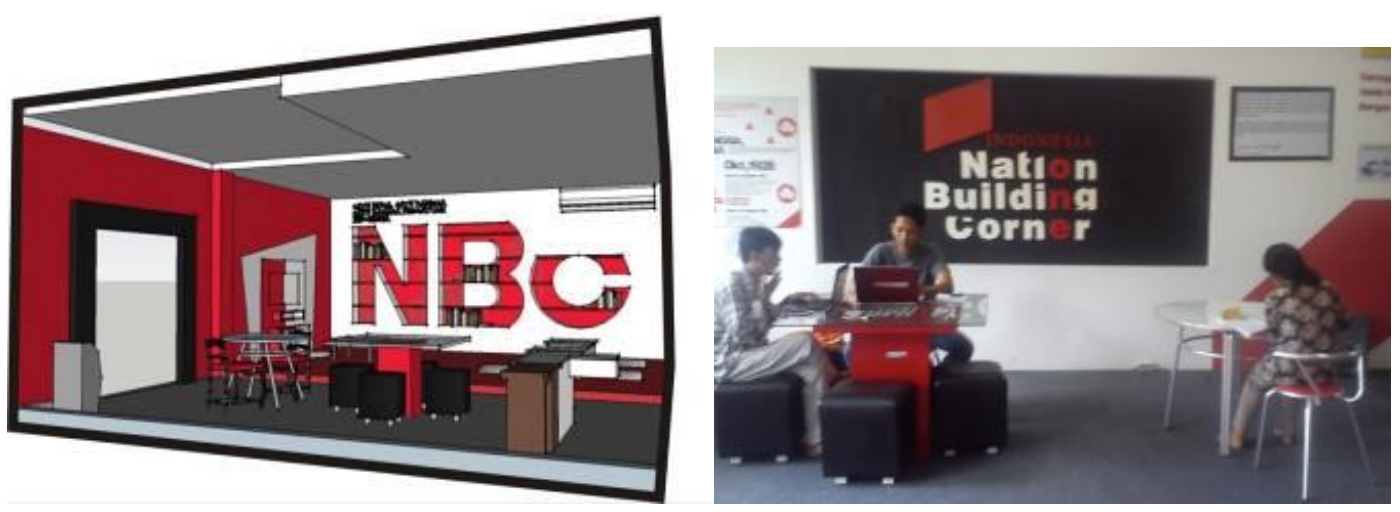

Gambar 1 National Building Corner (NBC) UGM (Sumber: Dokumentasi Penulis, 2018)

Lingkungan mempengaruhi perilaku manusia, orang cenderung duduk suatu tempat yang biasanya ditempati meskipun tempat tersebut bukan tempat duduk. Perilaku manusia juga mempengaruhi lingkungan, Ketika orang cenderung memilih jalan pintas, mereka pikir mereka bisa paling dekat dibanding dengan pejalan kaki yang berputar (Novrial and Marina Dwi 2019). Apabila ruang dibatasi, sebagian besar pengguna akan melakukan banyak kegiatan yang di luar fungsinya karena masalah tata ruang. Jadi, meskipun ruang tersebut milik publik, sebagian besar ruang telah dikuasai sebagai area pribadi (Tatyana, Adianto, and Gabe 2019).

Dalam studi perilaku ada beberapa teori pendekatan yang dapat digunakan Salah satu nya adalah pendekatan Semiotik, Semiotik adalah ilmu tentang tanda-tanda. Semiotik terdiri dari tiga komponen, yaitu:

1. Sintak yaitu hubungan antara pertanda dalam suatu sistem pertanda

2. Semantik yaitu hubungan antara pertanda dengan sesuatu yang diwakilinya yang menjelaskan makna pertanda tersebut

3. Pragmatik yaitu hubungan antara pertanda dengan hubungan manusia

Aspek tematik dalam kajian semantik menjadi hal yang sangat penting diperhatikan, hal ini karena aspek tematik dapat menampilkan pengorganisasi bentuk untuk meberikan satu penekanan pada sebuah sistem tanda (Juodinytè-Kuznetsova 2014). Dan sebagai sebuah produk sitem tanda, ruang juga dapat mengalami proses temastisasi yang menjelaskan sifat dan kareakteristik ruang. Setiap ruang dapat dianggap sebagai sebuah media untuk menyampaikan pesan tertentu sehingga pada beberapa ruang dengan fungsi yang sama memiliki bentuk yang sama pula (Farbstein and Kantrowitz 1978).

Sedangkan secara pragmatik, Umberto Eco juga menganggap bahwa fungsi utama bangunan dapat dipisahkan dalam aspek denotasi dan aspek konotasi sehingga menjadikan antara makna primer dan makna sekunder juga terpisah satu sama lain (Wahid and Alamsyah 
2013). Umberto Eco menjelaskan bahwa meski objek arsitektur memiliki makna primer yang utama namun dia juga berpendapat bahwa terdapat makna sekunder berupa interpretasi objek arsitektur tidak bisa dikontrol oleh arsitek maupun desainernya, karena arsitektur sebagai sistem tanda tidak berdiri untuk dirinya sendiri melainkan membutuhkan satu pemaknaan dari lingkungan yang ada di sekitarnya (Ebsen 2010).

Secara Fisik National Building Corner Universitas Gadjah Mada memiliki struktur dan layout ruang yang berbeda dengan sebagian besar ruang perpustakaan. Dengan tipikal ruang persegi dan desain lantai yang terbagi menjadi dua area yakni area duduk dan area lesehan, area lesehan terdiri atas 3 set meja lesehan dengan alas duduk pada dua sisinya (kode L1, L2, dan L3) dengan alas lantai karpet berwarna merah terang membuat area lesehan ini sangat menonjol diatara area yang lain dalam ruang. Diantara set meja juga terdapat area kosong yang cukup luas untuk dimanfaatkan sebagai area diskusi pengunjung ruang National Building Corner, selain itu juga terdapat rak buku customized yang berbentuk inisial National Building Corner pada dinsing berwarna putih menambah kesan unik pada area ini. Sedangan pada area duduk terdapat 2 set meja duduk, set pertama (D1) terdiri atas meja persegi dengan 4 bench si setiap sisinya, dan set kedua berupa meja round table dengan 2 kursi bulat (D2), pada area duduk ini juga terdapat meja admin yang memberikan pelayanan peminjaman buku kepada pengunjung

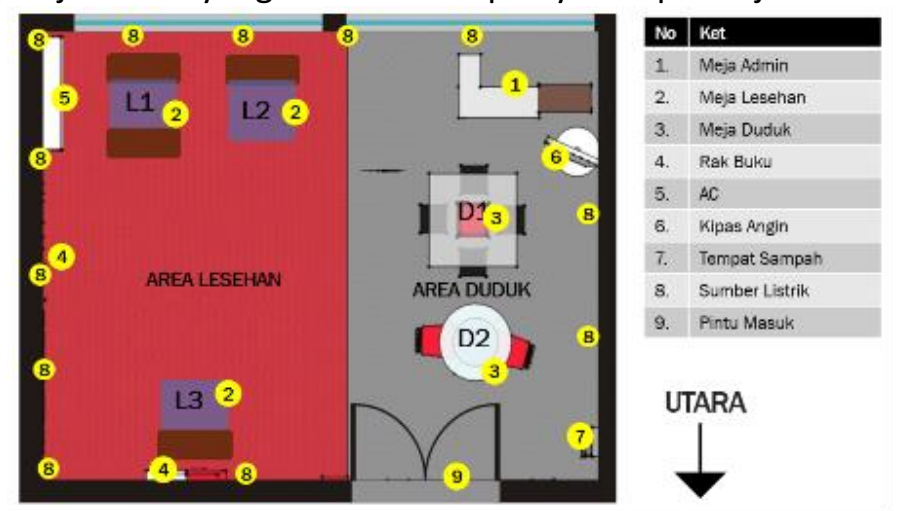

Gambar 2 Denah National Building Corner UGM

(Sumber: Penulis, 2018)

Denah ruang National Building Corner UGM menghadap sisi utara gedung, terdiri atas 2 bagian, area duduk terdapat 2 set meja dengan masing-masing 4 tempat duduk yang diperuntukkan untuk pengunjung yang dating berkelompok, sedang di area lesehan ditempatkan meja pendek individual

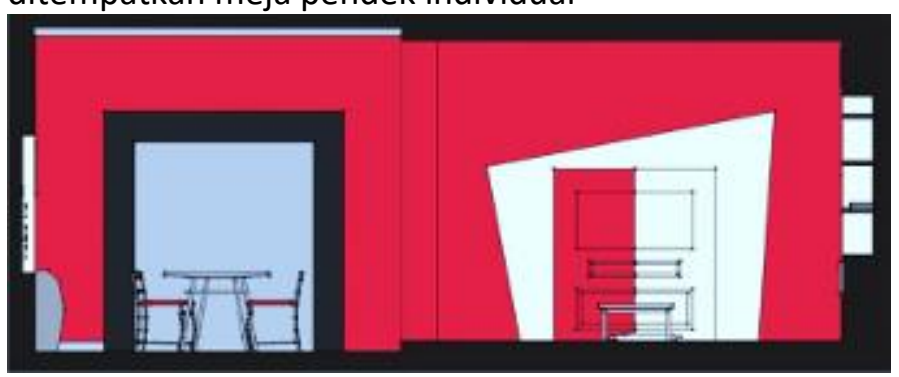

Gambar 3 Tampak Utara National Building Corner UGM

(Sumber: Penulis, 2018)

Tampak sisi utara ruang terdapat pintu masuk dari kaca dengan frame warna hitam solid, dinding disisi ini di dominasi dengan warna merah dengan kombinasi putih pada bagian rak buku dan TV head board yang menyatu dengan partisi trapezium. TV ini juga menyajikan video 
informasi-informasi yang berkaitan dengan layanan dan buku-buka yang ada pada layanan National Building Corner Universitas Gadjah Mada

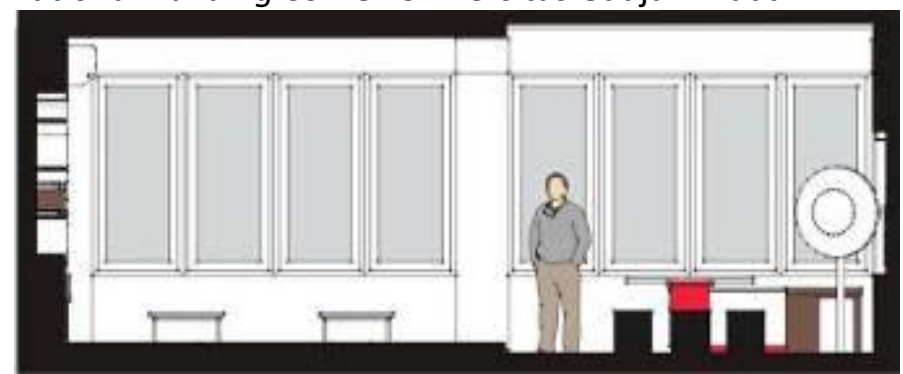

Gambar 4 Tampak Selatan National Building Corner UGM

(Sumber: Penulis, 2018)

Tampak selatan merupakan dinding yang berbatasan langsung dengan sisi luar perpustakaan, sehingga di dominasi oleh kaca bukaan bawah yang menjadi sumber pencahayaan dan penghawaan alami untuk ruangan.

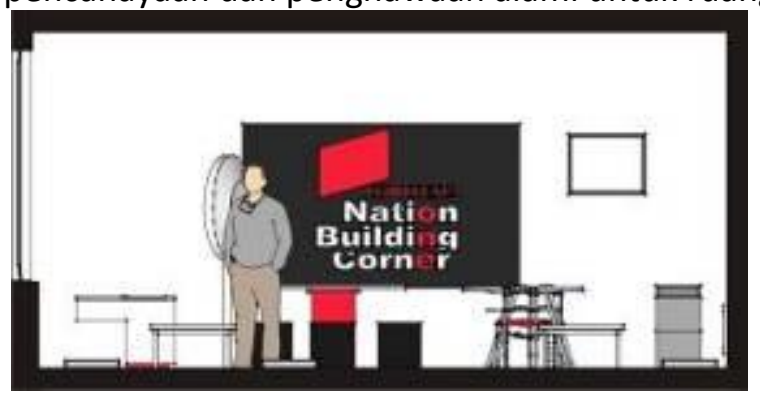

Gambar 5 Tampak Barat National Building Corner UGM

(Sumber: Penulis, 2018)

Pada sisi barat terdapat papan inisial National Building Corner Universitas Gadjah Mada dengan frame hitam pada dinding putih yang membuat kontras desain terfokus pada inisial ruang tersebut terdapat hiasan dinding dan plakat peresmian ruangan.

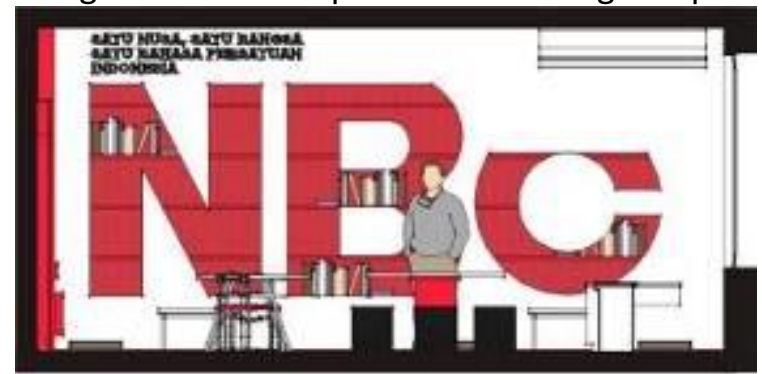

Gambar 6 Tampak Timur National Building Corner UGM

(Sumber: Penulis, 2018)

Pada sisi timur, dinding di isi dengan desain tematik berupa rak buku yang di sesain dengan sedikit menjorok ke dalam dinding dan berinisal NBC sehingga sangat menarik perhatian pengunjung untuk mendekat ke area ini. Buku-buku koleksi layanan juga tepajang pada rak ini sehingga Sebagian besar pengunjung yang ingin membaca koleksi layanan akan mendekat kerak buku ini untuk mecari judul buku yang akan dibaca.

Tata Perilaku (behavior setting) dapat diartikan secara sederhana sebagai suatu interaksi antara suatu kegiatan dengan tempat yang spesifik. Dengan demikian behavior setting mengandung unsur-unsur sekelompok orang yang melakukan sesuatu kegiatan, aktivitas atau perilaku dari sekelompok orang tersebut, tempat dimana kegiatan tersebut dilakukan, serta waktu spesifik saat kegiatan tersebut dilaksanakan. Behavior setting dijabarkan dalam dua istilah 
yakni system of setting dan system of activity dimana keterkaitan dua hal ini membentuk satu behavior setting tertentu (Zohrah and Hartono 2005). System of setting merupakan tempat atau ruang yang diartikan sebagai rangkaian unsurunsur fisik atau spasial yang mempunyai hubungan tertentu dan terkait hingga dapat dipakai untuk suatu kegiatan tertentu. Sementara system of activity atau sistem kegiatan diartikan sebagai suatu rangkaian perilaku yang secara sengaja dilakukan oleh satu atau beberapa orang.

Terjadinya interaksi antara manusia dengan lingkungan disebut dengan persepsi. Kesesuaian karakteristik dalam interaksi manusia dengan lingkungan sekitarnya sangatlah penting dalam pengembangan suatu lingkungan binaan (Muthiasari and Ernawati 2018). Tata perilaku berkaitan erat dengan lingkungan fisik. Elemen penting dalam behavior setting meliputi sekelompok orang sebagai pelaku aktivitas, perilaku atau aktivitas, tempat terjadinya aktivitas, serta waktu spesifik saat aktivitas tersebut berlangsung. Analisis behavior setting dapat dilakukan melalui Behavior Mapping (Pradani and Nurini 2020). Tujuannya adalah untuk menggambarkan perilaku dalam peta, mengidentifikasikan jenis dan frekuensi perilaku, serta menunjukkan kaitan antara perilaku tersebut dengan wujud perancangan yang spesifik.

\section{Metode Penelitian}

Penelitian ini menggunakan pendekatan studi tata perilaku dalam kerangka paradigma rasionalistik dan metode penelitian kualitatif dengan melakukan jenis observasi pada interval waktu tertentu dan selama observasi, pemetaan perilaku digunakan untuk mencatat lokasi pengguna dan pola perilakunya (Nizarudin 2016). Pengamatan langsung dilakukan untuk mendapatkan gambaran pemetaan perilaku pengguna National Building Corner Universitas Gadjah Mada, dengan metode place centered map yakni dengan menjadikan ruang National Building Corner sebagai fokus amatan dalam studi perilaku ini.

Untuk mempelajari lebih lanjut tentang studi perilaku ini, aktivitas dicatat dalam kerangka waktu yang berbeda dalam satu hari dan dibandingkan untuk mempelajari polanya, misalnya, waktu untuk aktivitas yang berbeda. Pergerakan aktivitas dalam kerangka waktu yang berbeda dan variasinya antara hari kerja dan akhir pekan juga dipertimbangkan (Do et al. 2019). Observasi dilakukan dengan pemilihan waktu amatan antara 1-2 jam disetiap varian waktu berbeda antara pagi, siang, sore dan malam hari baik dihari kerja maupun di hari weekend.

Studi tata perilaku dengan melakukan survei lokasi dan pemetaan perilaku yang mendetail dapat mengungkapkan secara lebih mendalam pemahaman tentang sebuah fenomena (Zakariya, Harun, and Mansor 2016). Oleh karena itu observasi dilakukan dengan melihat dan merasakan langsung fenomena aktual di lapangan lalu direkam dalam ilustrasi dan coding tertentu sesuai dengan karakteristik perilaku pengguna ruang perpustakaan National Building Corner Universitas Gadjah Mada. Pemetaan perilaku dilakukan dengan teknik pengkodean setiap jenis perilaku pengunjung National Building Corner untuk memudahkan dalam proses analisis studi perilaku. behavioral mapping digambarkan dalam bentuk sketsa atau diagram mengenai suatu area dimana manusia melakukan berbagai kegiatannya. Tujuannya adalah untuk menggambarkan perilaku dalam peta, mengidentifikasikan jenis dan frekuensi perilaku, serta menunjukan kaitan antara perilaku tersebut dengan wujud perancangan yang spesifik (Pamungkas and Arsandrie 2020). 


\section{Hasil dan Pembahasan}

Pembahasan penelitian ini dilakukan dengan analisis pemetaan perilaku dilakukan dengan pengelompokan beberapa perilaku dalam tema ruang tertentu untuk memperoleh gambaran general tentang zona-zona dalam ruang fisik yang dimanfaatkan untuk jenis-jenis perilaku tertentu. Pengkodean perilaku ini didasarkan atas kedekatan sifat dan karakteristik perilaku yang muncul. Pengkodean dilakukan untuk memberikan gambaran zonasi jenis kegiatan yang berlangsung dalam ruang, dengan demikian diharapkan keluaran zonasi ini dapat membantu memberikan penjelasan tentang tata perilaku pengunjung National Building Corner Universitas Gadjah Mada dalam mengokupasi ruang yang tersedia. Dari beberapa pengamatan langsung yang dilakukan jenis aktivitas yang terjadi dalang setting fisik National Building Corner Universitas Gadjah Mada dapat dilihat dari gambar berikut:

\begin{tabular}{|l|l|r|}
\hline No & Perilaku & Sim \\
\hline 1. & Membaca buku & $\mathbf{D}$ \\
\hline 2. & $\begin{array}{l}\text { Mengetik dengan } \\
\text { Laptop }\end{array}$ & $\mathbf{C}$ \\
\hline 3. & Menulis & $\boldsymbol{\Delta}$ \\
\hline 4. & $\begin{array}{l}\text { Internet dengan } \\
\text { Laptop }\end{array}$ & $\mathbf{A}$ \\
\hline 5. & Mendengarkan Musik & $\mathbf{O}$ \\
\hline 6. & Makan & $\mathbf{O}$ \\
\hline 7. & Minum & $\mathbf{Q}$ \\
\hline 8. & Menggunakan Gadget & $\mathbf{X}$ \\
\hline 9. & Diskusi/Ngobrol & $\mathbf{7}$ \\
\hline
\end{tabular}

Gambar 7 Pengkodean Perilaku

(Sumber : Penulis, 2018)

\section{Behaviour Mapping}

Mendalami ruang melalui peta perilaku merupakan sebuah proses pemindaian yang optimal yang dapat mengarahkan kepada pengambilan keputusan desain yang baik. Peta perilaku (behaviour mapping) dapat dilihat sebagai penghubung langsung antara pengguna diruang dan bentuk fisik serta fungsionalitas tempat itu sendiri (Marušić and Marušić 2012). Dari hasil observasi dan pengamatan langsung pada rentan waktu tertentu, analisis terhadap pola tata perilaku pengguna ruang National Building Corner. maka dapat dipetakan tata perilaku pengguna pada ruang National Building Corner Universitas Gadjah Mada berdasarkan hari (weeksday - weekend) dan waktu (Pagi - Siang - Sore) seperti table di bawah : 
Tabel 1 Behaviour Maping National Building Corner UGM

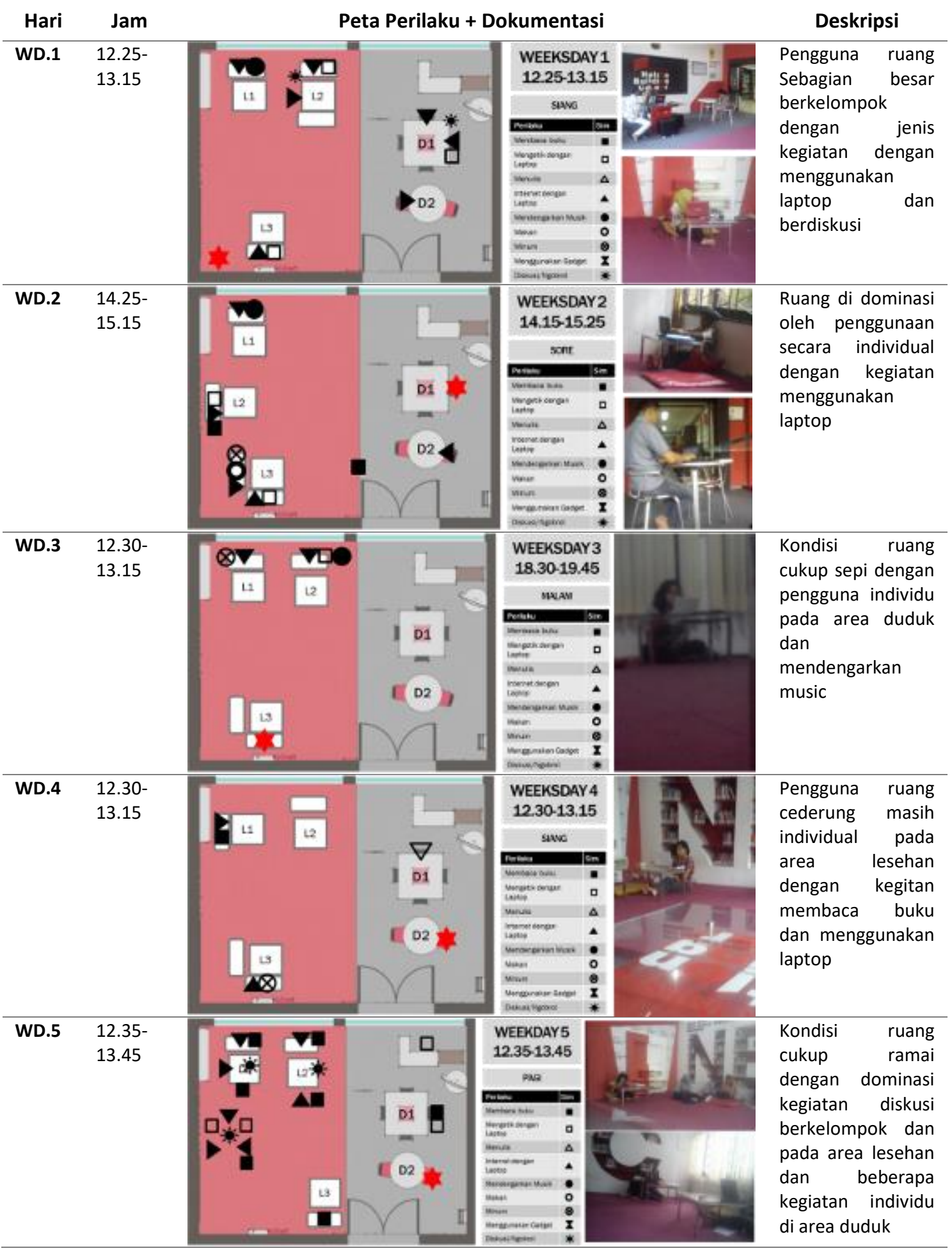




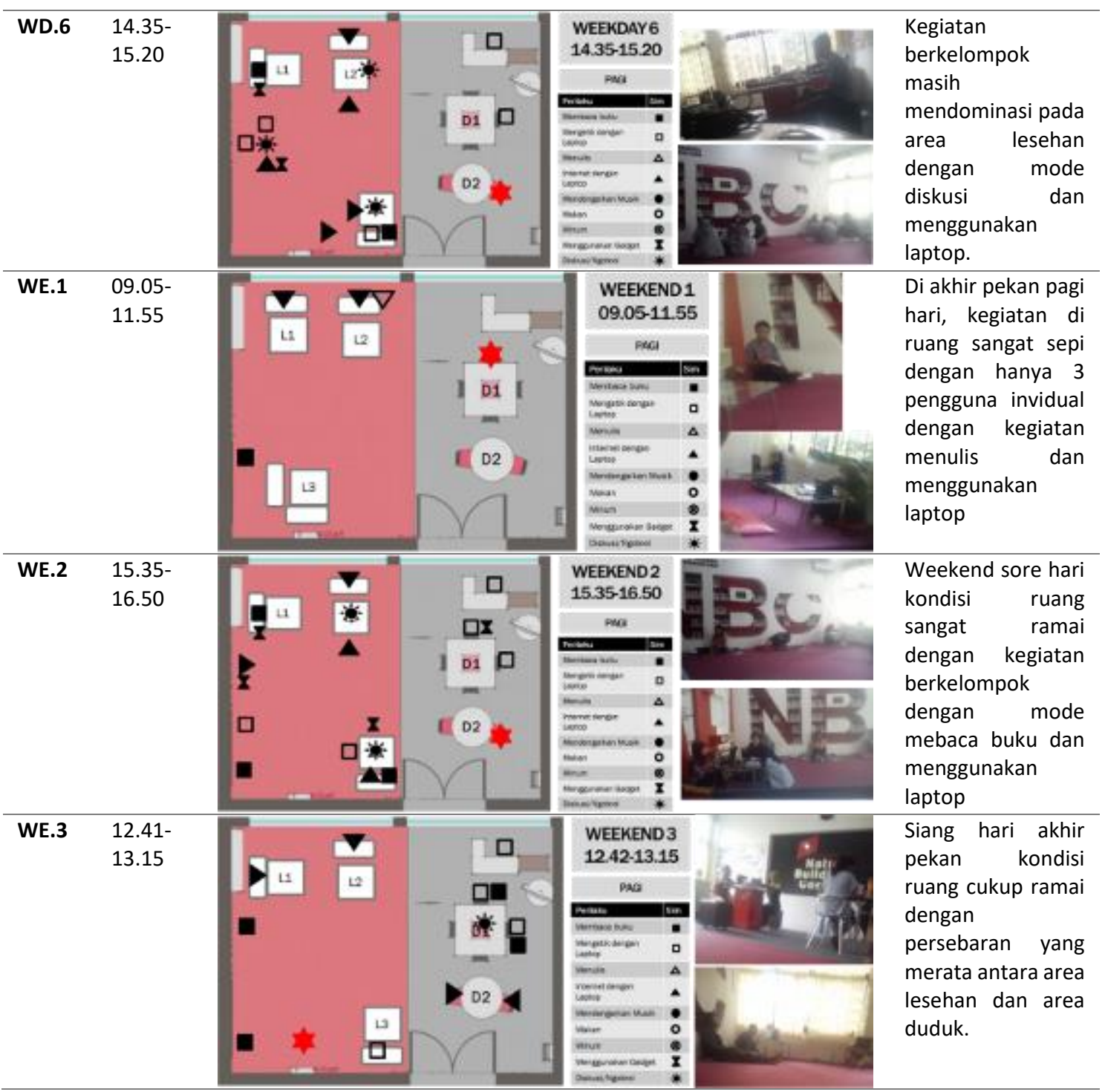

(Sumber : Analisis Penulis, 2018)

Hasil pengamatan tata perilaku di atas menunjukan konsentrasi aktivitas cenderung di area lesehan, hal ini dikarenakan setting fisik yang fleksibel di area lesehan membuat pengunjung dapat melakukan berbagai jenis aktivitas di area tersebut, sedangkan di area duduk yang cenderung formil dan kurang dinamis, aktivitas mengetik menggunakan laptop atau mengerjakan tugas kuliah sering terjadi karena aktivitas ini cenrung individu dan membutuhan suasana yang serius. Dalam ruang National Building Corner Universitas Gadjah Mada cenderung di dominasi oleh aktivitas individu di dua area lesehan dan area duduk, sedangkan untuk kegiatan berkelompok hanya sering terlihat di area lesehan yang memang memiliki fleksibilitas ruang yang baik.

Tabel 2 Tabel Kuantifikasi Perilaku dalam Ruang

\begin{tabular}{|c|c|c|c|c|c|c|c|c|c|c|}
\hline \multirow{2}{*}{ Waktu } & \multirow{2}{*}{ Area } & \multicolumn{8}{|c|}{ Aktivitas } & \multirow[b]{2}{*}{ Total } \\
\hline & & & & & & & & & & \\
\hline \multirow[t]{2}{*}{ Weekday 1} & Lesehan & & & 2 & 2 & 1 & & & 1 & 6 \\
\hline & Duduk & & & 1 & 3 & & & & 1 & 5 \\
\hline Weekday 2 & Lesehan & 2 & 2 & & 4 & 1 & 1 & 1 & & 9 \\
\hline
\end{tabular}




\begin{tabular}{|c|c|c|c|c|c|c|c|c|c|c|c|}
\hline & Duduk & & & & 1 & & & & & & 1 \\
\hline \multirow[t]{2}{*}{ Weekday 3} & Lesehan & & 1 & & 2 & 1 & & 1 & & & 5 \\
\hline & Duduk & & & & & & & & & & 0 \\
\hline \multirow[t]{2}{*}{ Weekday 4} & Lesehan & & 1 & & 2 & & & 1 & & & 4 \\
\hline & Duduk & & & 1 & & & & & & & 1 \\
\hline \multirow[t]{2}{*}{ Weekday 5} & Lesehan & 6 & 2 & & 7 & & & & & 3 & 18 \\
\hline & Duduk & 1 & 1 & & & & & & & & 2 \\
\hline \multirow[t]{2}{*}{ Weekday 6} & Lesehan & 2 & 3 & & 5 & & & & 2 & 3 & 15 \\
\hline & Duduk & & 2 & & & & & & & & 2 \\
\hline \multirow[t]{2}{*}{ Weekend 1} & Lesehan & 3 & 2 & & 4 & & & & 3 & 2 & 14 \\
\hline & Duduk & & 3 & & & & & & 1 & & 4 \\
\hline \multirow[t]{2}{*}{ Weekend 2} & Lesehan & 2 & 1 & & 2 & & & & & & 5 \\
\hline & Duduk & 2 & 3 & & 2 & & & & & 1 & 8 \\
\hline \multirow[t]{2}{*}{ Jumlah } & Lesehan & 15 & 12 & 2 & 28 & 3 & 1 & 3 & 5 & 9 & 76 \\
\hline & Duduk & 3 & 9 & 2 & 6 & 0 & 0 & 0 & 1 & 2 & 23 \\
\hline \multirow[t]{2}{*}{$\%$} & Lesehan & 19 & 15 & 3 & 36 & 4 & 1 & 4 & 6 & 12 & 78 \\
\hline & Duduk & 13 & 39 & 9 & 26 & 0 & 0 & 0 & 4 & 9 & 23 \\
\hline
\end{tabular}

(Sumber : Analisis Penulis, 2018)

Dari tabel di atas terlihat kuantifikasi aktivitas dalam ruang ini, menghasilkan kecenderungan jenis aktivitas yang mendominasi dalam ruang secara keseluruhan yakni aktivitas internet dengan menggunakan laptop dimana sekitar $36 \%$ pengunjung area lesehan melakukan aktivitas internet dengan laptop ini, sedangkan di area duduk sekitar $26 \%$ dari pengunjungnya. Selain itu aktivitas mengerjakan tugas denga laptop juga cenderung mendominasi meskipun hanya pada area duduk dengan presentase $39 \%$ dari total pengunjung area duduk, sedangkan pada area lesehan hanya sekitar $15 \%$ saja. Hal ini membuat kegiatan menggunakan laptop baik untuk mengerjakan tugas maupun mengakses internet menjadi tata perilaku paling dominan di ruang National Building Corner Universitas Gadjah Mada.

\section{Behaviour Setting / Tata Perilaku}

Behaviour setting didefinisikan sebagai suatu kombinasi yang stabil antara aktivitas, tempat, dan kriteria tertentu (Nurzamni and Marlina 2019). Dari pemetaan tata perilaku di atas terlihat bahwa untuk aktivitas edukasi pengunjung cenderung memilih tempat di area lesehan dengan orientasi mengikuti garis dinding ruang, pemilihan ini dikarenakan dengan duduk mengikuti garis dinding ruang maka pengunjung dapat menjaga privacy aktivitas yang merekan kerjakan, meski harus duduk berdekatan dengan pengunjung lain. Karena sebagaian besar aktivitas dilakukan dengan peralatan laptop, maka kerahasian aktivitas yang dilakukan pada laptop tersebut menjadi proiritas pengunjung dalam memilih posisi duduk. 


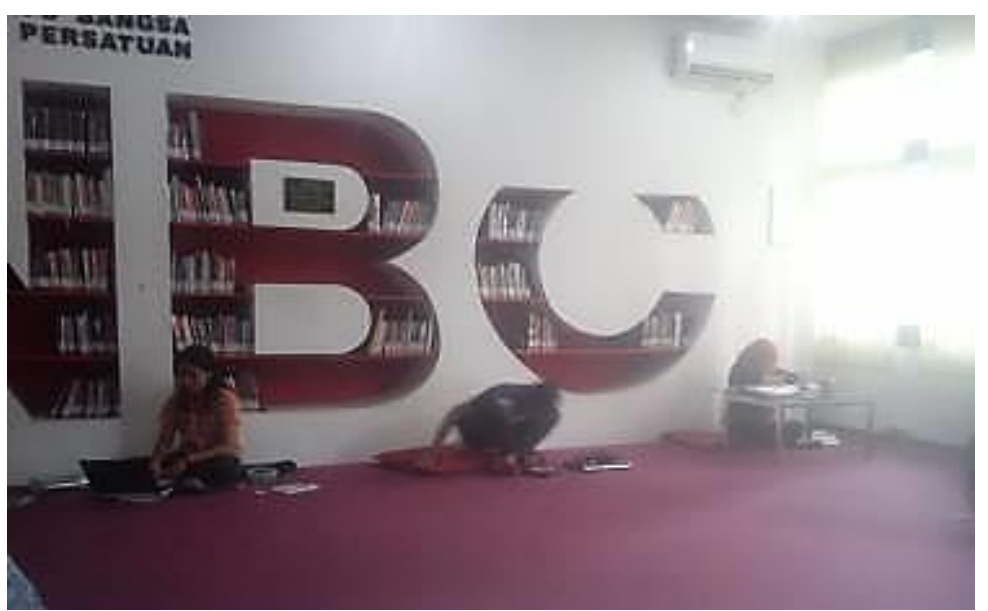

Gambar 8 Tata Perilaku Individu

(Sumber: Dokumentasi Penulis, 2018)

Demikian pula yang terjadi pada jenis aktivitas hiburan, karena aktivitasnya juga menggunakan peralatan laptop, maka privacy laptop menjadi pertimbangan mengapa pengunjung kategori ini cenderung memilih area garis dinding ruang.

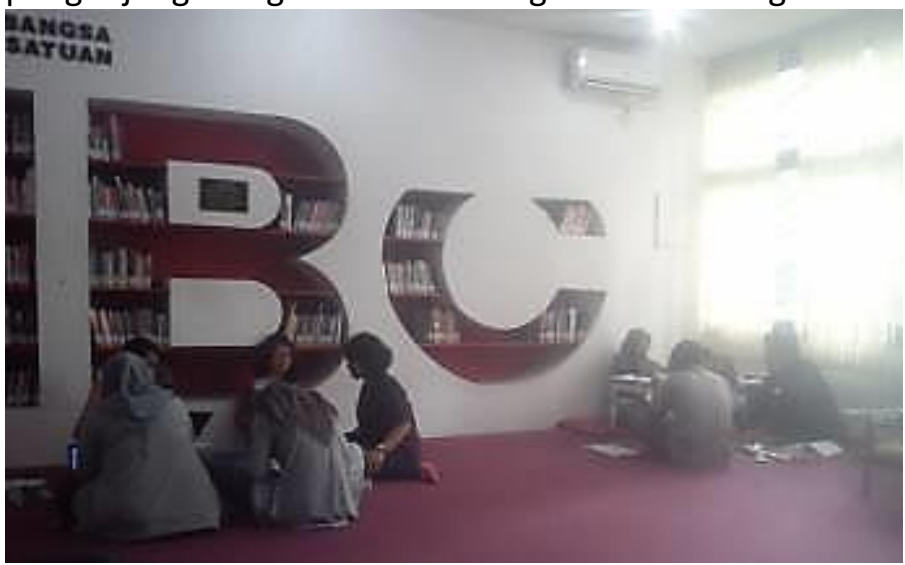

Gambar 9 Tata Perilaku Berkelompok

(Sumber: Dokumentasi Penulis, 2018)

Untuk kelompok yang datang untuk kegiatan diskusi dengan beberapa anggota, maka petimbangan utamanya adalah keluasaan volume ruang untuk semua anggota, maka kelompok ini cenderung menempati ruang ruang tengah yang tersisa oleh pengunjung lain yang melakukan aktivitas secara individu.

\section{Simpulan}

Dari hasil analisis kuantifikasi ruang yang di-overlay pada setting fisik National Building Corner Universitas Gadjah Mada, maka ditemukan kecenderungan peta tata perilaku kegiatan dalam area tertentu ini membentuk suatu proses tematisasi ruang. Tema ruang ini terbentuk atas pengaruh tata perilaku yang terjadi pada saat itu. Pada saat pengunjung sebagian besar melakukan kegiatan membaca buku, mengetik dengan laptop, dan menulis di buku. Maka saat itu tema ruang yang terjadi pada National Building Corner Universitas Gadjah Mada adalah tema ruang edukasi seperti gambar dibawah ini. 

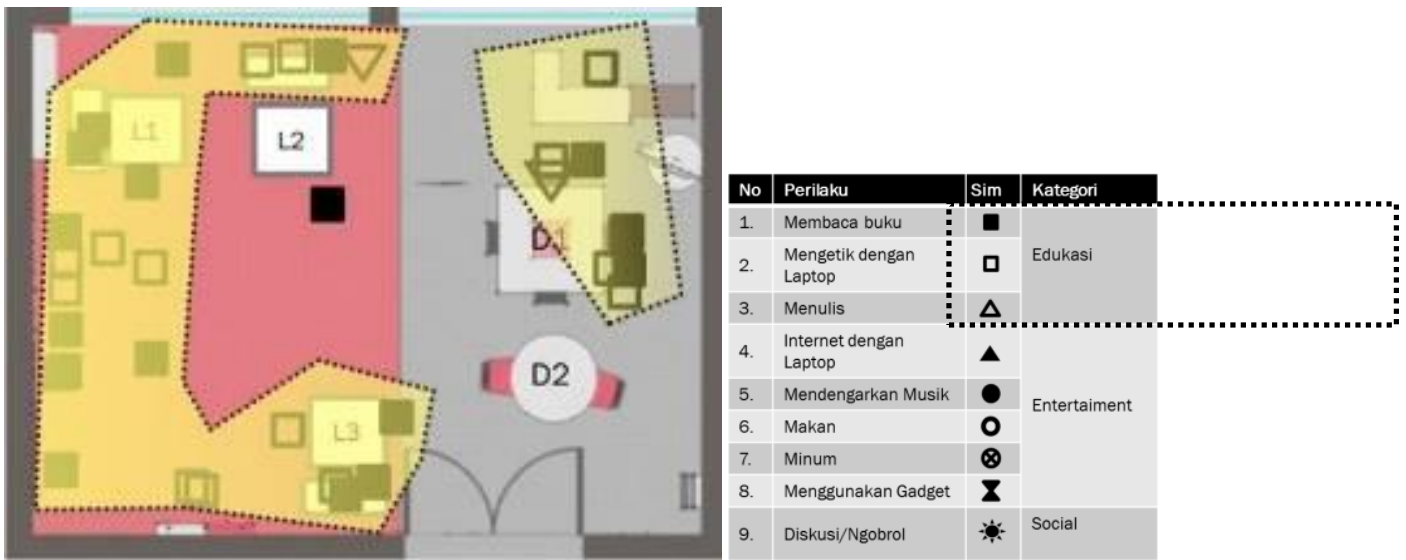

Gambar 10 Tata Perilaku Dalam Tema Ruang Edukasi

(Sumber: Penulis, 2018)

Begitupun saat tata perilaku mengakses internet, mendengarkan musik, makan, minum, dan menggunakan gadget terpolarisasi dalam satu area tertentu, maka terjadilah tematisasi ruang yang bersifat entertainment di National Building Corner Universitas Gadjah Mada. Dan apabila kegiatan diskusi dalam jumlah yang besar antara pengunjung maka serta merta tema tuang pun berubah menjadi tema ruang sosial.

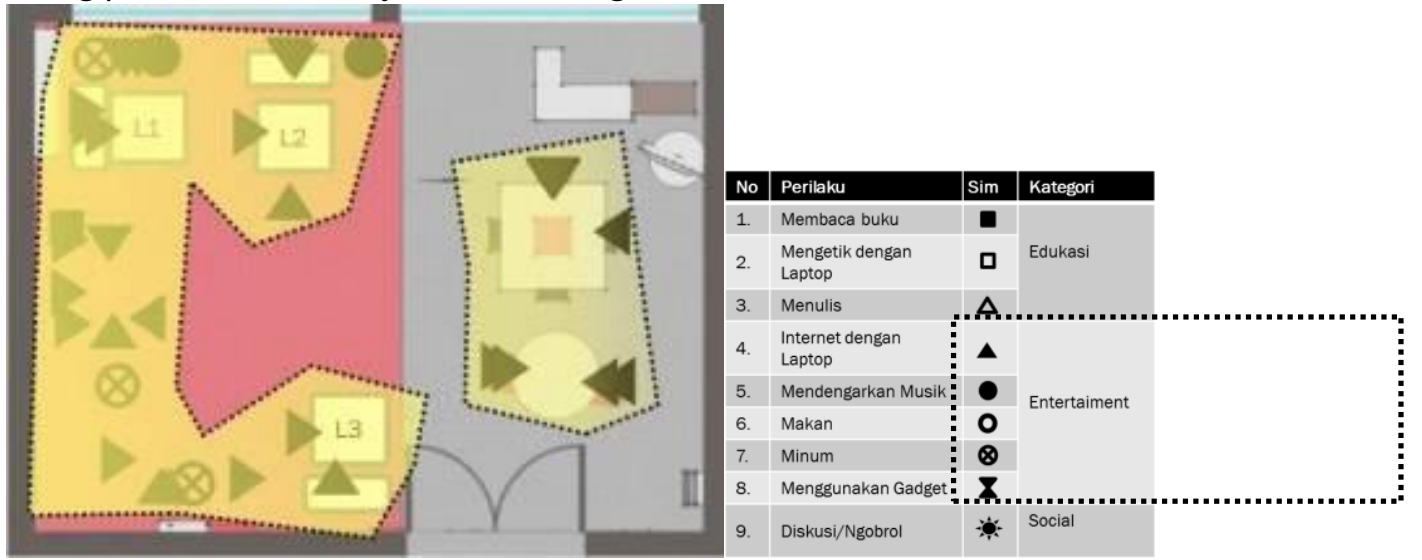

Gambar 11 Tata Perilaku Dalam Tema Ruang Hiburan

(Sumber: Penulis, 2018)
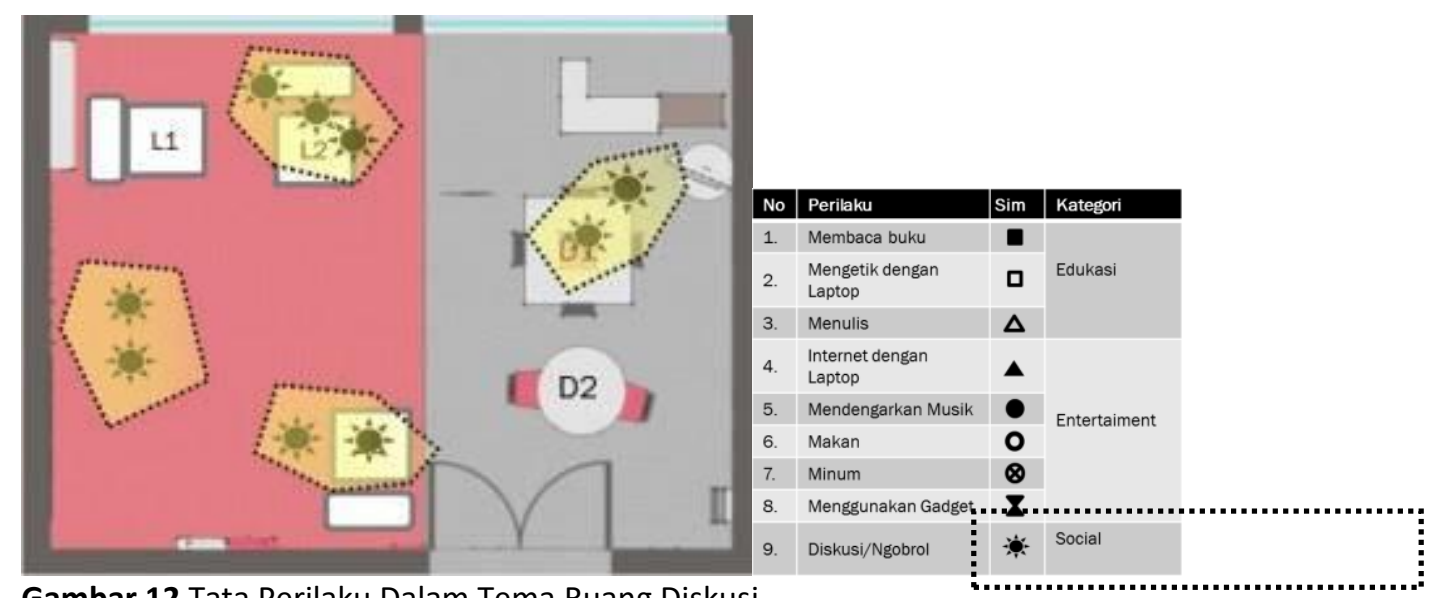

Gambar 12 Tata Perilaku Dalam Tema Ruang Diskusi

(Sumber: Penulis, 2018) 
Hal ini memberikan kesimpulan bahwa fleksibilitas tema ruang yang terjadi di ruang National Building Corner Universitas Gadjah Mada ini banyak dipengaruhi oleh tata perilaku pengguna ruang dalam mengokupansi area yang ada. Meskipun pada awalnya ruangan ini di desain dengan tujuan dan tema tertentu, ternyata hal ini dapat senantiasa berubah sesuai dengan tata perilaku pengguna ruang nya. Dengan kecenderungan tiga tema ruang dengan polanya masing-masing, maka terlihat keterkaitan antara satu dengan yang lainnya. Dimana perilaku dalam kategori edukasi dan kategori hiburan cenderung saling tumpang tindih pada satu area yang sama yakni pada area sisi dinding ruangan National Building Corner Universitas Gadjah Mada sedangkan kategori aktivitas berkelompok akan menempati ruang yang tersisa oleh kegiatan edukasi dan hiburan, Meskipun dalam rentan waktu yang bersamaan ketiga kategori kegiatan ini diwadahi dalam setting fisik National Building Corner Universitas Gadjah Mada.

Dari studi tata perilaku di atas dapat ditarik bebrapa kesimpulan sebagai berikut:

1. Tata perilaku pengunjung mempengaruhi tema ruang. Dimana tema ruang edukasi cenderung memetakan diri pada area duduk yang setting fisiknya cenderung lebih formil dan kurang dinamis, sedangkan tema ruang hiburan menempatkan diri pada area lesehan yang lebih fleksibel dalam setting fisiknya

2. Adanya perbedaan pertimbangan dalam pola perilaku antara pengunjung individu dengan pengunjung yang datang berkelompok. Pengunjung individu cenderung menempatkan diri pada sisi garis dinding ruang untuk menjaga kerahasian mereka, sedangkan pengunjung berkelompok lebih mempertimbangkan volume ruang yang mencukupi untuk anggota kelompoknya.

\section{Ucapan Terima Kasih}

Ucapan terima kasih kepada tim editorial jurnal desain atas koreksi dan reviewnya terhadap artikel ini, afiliasi peneliti Universitas Islam Negeri Alauddin Makassar, dan Universitas Gadja Mada sebagai lokus penelitian ini diselenggarakan, serta semua pihak yang mendukung penulisan artikel ini.

\section{Daftar Pustaka}

Do, Duy Thinh, Yuning Cheng, Amir Shojai, and Ye Chen. 2019. "Public park behaviour in Da Nang: An investigation into how open space is used." Frontiers of Architectural Research 8 (4): 454-470. https://doi.org/10.1016/i.foar.2019.05.006.

Ebsen, Tobias. 2010. "Towards a Media Architecture: An inquiry into the convergencies of constructed space and screen-based media." PhD Dissertation, Faculty of Art, Aarhus University.

Farbstein, Jay, and Min Kantrowitz. 1978. People in places: Experiencing, using, and changing the built environment. Prentice Hall.

Juodinytè-Kuznetsova, Kristina. 2014. "Architectural space and Greimassian semiotics." Socialiniy Moksly Studijos Societal Studies 3 (4): 1269-1280. https://repository.mruni.eu/bitstream/handle/007/11039/778-1435-1SM.pdf? sequence $=2 \&$ isAllowed $=\mathbf{y}$. 
Marušić, Barbara Goličnik, and Damjan Marušić. 2012. "Behavioural Maps and GIS in Place Evaluation and Design." In Application of Geographic Information Systems, edited by Bhuiyan Monwar Alam, 115-138. London: IntechOpen Limited.

Muthiasari, Garcia, and Atie Ernawati. 2018. "Perancangan Panti Sosial untuk Penyandang Tunaganda dengan Pendekatan Arsitektur Perilaku." Jurnal Desain 5 (03): 189-205. https://doi.org/10.30998/jurnaldesain.v5i03.2392.

Nizarudin, Norhanis Diyana. 2016. "Spatial and Sociocultural Aspects of Urban Mosque Open Spaces in Kuala Lumpur, Malaysia: A mixed-method approach." Environment-Behaviour Proceedings Journal 1 (2): 43-51. https://doi.org/10.21834/e-bpj.v1i2.254.

Novrial, and Avisha Marina Dwi. 2019. "Study of Physical Traces Toward Activities and Behaviour of Public Open Space Users (Case Study: Merdeka Square of Binjai City)." International Journal of Architecture and Urbanism 3 (3): 298-309. https://doi.org/10.32734/ijau.v3i3.3745.

Nurzamni, Dewanti Hari, and Avi Marlina. 2019. "Identifikasi Pola Perilaku pada Ruang Komunal Angkringan." Region: Jurnal Pembangunan Wilayah dan Perencanaan Partisipatif 14 (1): 66-79. https://jurnal.uns.ac.id/region/article/view/22164.

Pamungkas, Hariyo, and Yayi Arsandrie. 2020. "Behavioral Mapping Dan Adaptasi Terhadap Lingkungan Pada Squatter Settlement." NALARs 19 (2): 115-130. https://doi.org/10.24853/nalars.19.2.115-130.

Pradani, Septyani Wahyu, and Nurini. 2020. "Perilaku Masyarakat di Ruang Terbuka Publik AlunAlun Kabupaten Blora." TATA LOKA 22 (1): 50-60. https://core.ac.uk/download/pdf/304914989.pdf.

Sari, Dian Perwita, and Diananta Pramitasari. 2019. "Perilaku Pemilihan Tempat Duduk Pada Perpustakaan Jurusan Teknik Arsitektur Universitas Gadjah Mada." Jurnal Arsitektur GRID 1 (1): 20-29. http://ejournal.unsa.ac.id/index.php/grid/article/view/258.

Tatyana, Winda Hutami, Joko Adianto, and Rossa Turpuk Gabe. 2019. "Negotiation of Objects in Urban Kampong Street: A Case Study in Ampiun Alley, Cikini." International Journal of Built Environment and Scientific Research 3 (1): 7-14. https://doi.org/10.24853/ijbesr.3.1.7-14.

Wahid, Julaihi, and Bhakti Alamsyah. 2013. Teori Arsitektur: Suatu Kajian Perbedaan Pemahaman Teori Barat dan Timur. Yogyakarta: Graha Ilmu.

Zakariya, Khalilah, Nor Zalina Harun, and Mazlina Mansor. 2016. "Space and Sociability: Mapping Melbourne's City Square." Asian Journal of Quality of Life 1 (2): 45-55. https://doi.org/10.21834/ajqol.v1i2.28.

Zohrah, Laila, and Rudi Hartono. 2005. "Studi Perilaku Mahasiswa Arsitektur Terhadap Kantin Jurusan Teknik Arsitektur Fakultas Teknik Universitas Lambung Mangkurat." INFOTEKNIK 